\title{
Opinions of Special Education Teachers about Teaching Reading and Writing to Mentally Retarded Children
}

\author{
Hatice ŞENGÜL* $\quad$ Nur AKÇİN**
}

\begin{abstract}
The main purpose of this research is to state the opinions of special education teachers about teaching reading and writing to mentally retarded students. This research is designed descriptively. The participants of the research are 100 special education teachers. The data is received by a questionnaire prepared by the researcher. According to the findings, it is seemed that special education teachers don't depend on only one method while teaching reading and writing but they especially use sound and sentence analysis methods. These methods are used for normally developed children. There is no method that is developed for mentally retarded children in Turkey. New methods that consider cognitive and learning features of mentally retarded children are needed.
\end{abstract}

Keywords: Mentally retarded children, special education teacher, methods of teaching reading and writing

\section{SUMMARY}

Purpose and Significance: The main purpose of this research is to state the opinions of special education teachers about teaching reading and writing to mentally retarded students. This research is important to evaluate applications made in our country in the light of methods and applications in foreign countries.

\footnotetext{
${ }^{*}$ School Counselor, Ministry of National Education. E-mail: htc-sngl@hotmail.com

** Assist. Prof. Dr. Marmara University, Faculty of Education.

E-mail: nakcin@marmara.edu.tr
} 
It is hoped that by these evaluations new suggestions are given for new practices that are based on a more systematic and theoretical basis for teaching reading and writing to mentally retarded children in Turkey.

Methods: This research is designed descriptively. In the research, views of 100 special education teachers on prerequisite skills in teaching reading and writing, teaching methods, teaching materials, methods of teaching evaluation and problems they face through teaching of reading and writing were taken by the questionnaire prepared by the researcher.

In this research, firstly the descriptive analysis of the findings has been carried out. As a result of the analysis, the similar answers from the teachers are accepted as common themes and the frequency and the percentage of these themes among the total answers have been calculated.

Results: According to the findings, it is seemed that special education teachers don't depend on only one method at teaching reading and writing but they especially use sound and sentence analysis methods. It has been found out that motor skills, audio-visual perception and distinction and holding a pencil are expected skills that a students should have by the teachers before they start to teach how to read and write. First reading and writing books, event cards, matching cards and spelling books are the most favourite materials used by special education teachers. It has been found out that teachers often use different games as matching word games during teaching. It has been observed that most of the teachers use observation, individual work papers and criterion-referenced tests as evaluation materials while teaching reading and writing. Besides, special education teachers have pointed out that they face a lot of problems because of lack of materials while teaching reading and writing.

Families not giving enough support to the children while teaching sessions, not supporting them efficiently at home, taking the mentally retarded children who have different levels of performance to the same class, having only one teacher in the special education classes and students' insufficient development of prerequisite skills in teaching reading and writing are the other problems that are often pointed out.

Discussion and Conclusions: According to the results, it is seemed that special education teachers use methods at teaching reading and writing which is more suitable for normally developed children. There is a need for new applications and methods to teach reading and writing to mentally retarded children. 


\title{
Zihinsel Yetersizliği Olan Öğrencilere Okuma Yazma Öğretme Konusunda Özel Eğitim Öğretmenlerinin Görüşleri
}

\author{
Hatice ŞENGÜL* Nur AKÇİN**
}

ÖZ. Bu araştırmanın genel amacı, özel eğitim öğretmenlerinin zihinsel yetersizliği olan öğrencilere okuma yazma öğretiminde kullandıkları yöntemlerle ilgili görüşlerini almaktır. Araştırma betimsel olarak desenlenmiştir. Araştırmada 100 özel eğitim öğretmeninin okuma yazma öğretiminde yer verdikleri ön koşul beceriler, öğretim yöntemleri, materyalleri, değerlendirme teknikleri ile öğretim sırasında karşılaştıkları sorunlara ilişkin görüşleri alınmıştır. Bulgulara göre, özel eğitim öğretmenlerinin okuma yazma öğretiminde tek bir yönteme bağlı kalmadıkları fakat ağırlıklı olarak ses ve cümle çözümleme yöntemlerini kullandıkları görülmüştür. Bu yöntemler normal gelişim gösteren çocuklara okuma-yazma öğretiminde kullanılan yöntemlerdir. Türkiye'de zihin engelli çocuklar için kullanılan özel bir yöntem yoktur. Zihin engelli çocukların bilişsel ve öğrenme özelliklerini dikkate alarak geliştirilmesi gereken yeni öğretim yöntemlerine ihtiyaç vardır.

Anahtar Sözcükler: Zihinsel engelli çocuklar, özel eğitim öğretmeni, okuma ve yazma öğretim yöntemleri

\footnotetext{
* Rehber Öğretmen ve Psikolojik Danışman, MEB. E-posta: htc-sngl@hotmail.com

** Yrd. Doç. Dr. Marmara Üniversitesi Eğitim Fakültesi E-posta: nakcin@marmara.edu.tr
} 


\section{GíRİș}

Zihin engelli bireylere okuma, yazma ve yazım kurallarını öğretmek amaçlı sistematik okuryazarlık öğretimi çok eskiye dayanmayan bir olgudur (Katims, 2000a). 1900lü yılların başında okuma zihin engelli bireyler için gerekli olmayan ve kazanımı imkânsız görülen bir beceri olarak görülmüştür. 1950 ve 19601 yıllarda ise eğitilebilir zihinsel engelli çocuklara işlevsel görsel sözcük öğretimi ile ilgili çalışmalar yapılmıştır (Singh ve Singh, 1986). Zihin engelli çocukların okuma öğretimine çok fazla önem verilmemiş (Browder, Wakeman, Spooner, Ahlgrim-Delzell ve Algozzine, 2006) okuma öğretimi mesleki ve sosyal beceri öğretimi kadar ağırlık kazanmamıştır (Katims, 2000). Bu grubun okuma öğrenme yeteneklerinin olmadığı düşünülmüş (Browder ve diğerleri, 2006) ve bu düşük zeka düzeyi ile açıklanmıştır (Conners, Atwell, Rosenquist ve Sligh, 2001).

Zihin engelli bireyler için günlük yaşam ve toplum içinde bağımsızlık kazanmak için okuma temel beceridir. Zihin engelli çocukların kaynaştırma ve toplumsal uyumu önem kazandıkça okuma gereksinimi daha da önemli hale gelmiştir (Singh ve Singh, 1986).

Hoogeveen, Smeets ve Lancioni (1989) zihin engelli çocukların okumay1 öğrenmedeki problemlerinin birçok faktörle ilgili olabileceğini söylemişlerdir. Bunlardan ilki harfleri ayırt etmekte yaşadıkları güçlüklerdir. Görsel karmaşıklık ve uyarandaki bütün parçaları algılayamama bu çocuklar için sorun olabilmektedir ( Hoogeveen ve diğerleri, 1989). İkinci faktör, harf/yazıbirim-ses ilişkisini öğrenmedeki güçlüklerdir. Harfler ve sesleri soyut uyaranlardır ve zihin engelli çocukların soyut uyaranları ve kavramları öğrenmede zorluklar yaşadıkları bilinmektedir. Üçüncü faktör ise, seslerin tek başına telaffuzunun diğer seslerle birleştiğinde ortaya çıkan sesten farklı olmasıdır. Bu noktada zihin engelli çocuklar sesleri birleştirip kelime haline getirmekte veya kelimelerin içindeki sesleri ayırt etmekte zorluk yaşayabilirler. Dördüncü faktör ise bazı dillerdeki harf/yazıbirim-ses ilişkisinin düzensizliği bu dillerde okuma kazanımını zorlaştırmaktadır. Son olarak ise öğretimsel yöntemle ilgili sorunlar yaşanabilmesidir. Birçok okuma öğretim yöntemi normal gelişim gösteren ya da öğrenme problemi olmayan çocuklara göre desenlendiği için ön beceriler ya da öğretimsel etkinliklerin programlanması zihinsel engelli çocuklar için yetersiz olabilmektedir (Hoogeveen ve diğerleri, 1989).

Hafif ve orta düzeydeki zihin engelli bireylerin okur-yazar olabilmeleri için sözcük tanıma, okuduğunu anlama, okuma hızını geliştirme ve yazma öğretimi yöntemlerini içeren birçok öğretimsel yöntem, materyal ve strateji 
geliştirmiş ve kullanılmıştır (Katims, 2000; 2001). Zihin engelli bireylere okuma-yazma öğretim yaklaşımları iki temel kategoriye ayrılmaktadır. Bunlar davranışsal yaklaşım ve sosyal etkileşimci yaklaşımdır.

\section{Davranışsal Yaklaşım}

Davranışsal yaklaşımda okuma-yazma önceden belirlenmiş, doğrusal olarak sıralanmış ve alt becerilere ayrılmış şekilde kazandırılır. Bu öğretim sistematiktir ve öğretmenin yönlendirmesi, önerileri ve öğrenciyi pekiştirmesi ile ilerler (Hedrick, Katims ve Carr,1999; Katims, 2000; Trent, Artiles ve Englert, 1998).

$\mathrm{Bu}$ yaklaşımda öğretime harf/yazıbirim -ses ilişkisinin kurulması ile başlanır. Harflerden sözcükler oluşturulur ve bu sözcükler cümlelerde kullanılır (Katims,2000).

Zihin engelli çocuklara okuma-yazma öğretiminde davranışsal ilkelerin kullanıldığ iki temel öğretim yöntemi vardır. Bunlar, okuma öğretiminin içerik ve anlamına odaklanan tüm sözcük ya da görsel sözcük öğretimi ile sözcüklerin fonik analizleri ve dilsel özelliklerine odaklanan çözümleyici/fonik analiz öğretimidir (Gottardo ve Rubin, 1991; Hedrick ve diğerleri, 1999; Nichtern,1974).

\section{Tüm Sözcük/Görsel Sözcük Öğretimi}

Davranışsal yöntemlerin kullanıldı ̆̆ görsel sözcük öğretiminde yapılandırılmış ve kesin bir öğretimle sözcükler seslere ve hecelere bölünmeden anlamlı bütünler olarak öğretilir ve öğretime en sık kullanılan sözcükler ile başlanır ( Browder ve Lalli;1991; Singh ve Singh;1986). Bu sözcüklere görsel sözcük dağarcığı denir. Davranışsal yaklaşımda görsel sözcük öğrenimi iki karmaşık beceri üzerinden kavramsallaştırılabilir. Bunlar; çocuğun sözcügü oluşturan harfleri birleşik ve bütün olarak görsel ayrımlaştırması ve bu görsel ayrımlaştırmayı başka etkinliklerde ve ortamlarda genellemesidir (Browder ve Lalli, 1991).

Zihin engelli çocuklara görsel sözcük öğretiminde kullanılan temelde iki yöntem vardır. Bunlardan biri yanlışsız öğretim yöntemi, diğeri ise deneme-yanılma yöntemidir (Browder ve Lalli,1991; Walsh ve Lamberts, 1979).

Zihin engelli çocuklara görsel sözcük öğretiminde yanlışsız öğretim yöntemlerinden tepki ipuçlarının sunulduğu bekleme süreli öğretim ile uyaran ipuçlarının kullanımına dayalı uyaran ipuçlarını silikleştirme ve uyarana şekil verme yöntemleri sık kullanılmaktadır (Browder ve Lalli,1991; Singh ve Singh,1986; Tekin-İftar ve Kırcaali-İftar, 2004). 
Deneme yanılma yöntemi ile görsel sözcük öğretimi ise okumanın doğruluğuna göre geribildirimlerde bulunarak yapılır (Browder ve Lalli,1991; Singh ve Singh,1986). Basılı sözcük çocuğa gösterilerek ve öğretmen tarafından yüksek sesle okunarak çocuğun okuması için öğretim yapılır. Çocuğun okuması doğru ise, çeşitli şekillerde pekiştirilir; yanlış ise hata düzeltme yöntemleri uygulanır ( Browder ve Lalli, 1991; Singh ve Singh,1986).

Dorry ve Zeaman (1975) uyaran ipuçlarını silikleştirerek 32 zihin engelli çocuğa okuma yazma öğretmişler ve görsel sözcükleri etkili bir şekilde öğrenebildiklerini görmüşlerdir. Barudin ve Hourcade (1990), orta ve ağır düzeydeki zihin engelli 32 çocuğa görsel sözcük öğretiminde sözcüğün yazılı olduğu kartın gösterimi, sözcük ile beraber resimsel ipucu kullanımı ve dokunsal/hareketsel yöntemlerinin etkililiğini araştırmışlardır. Zihin engelli çocukların görsel sözcükleri öğrenmede başarılı oldukları ortaya çıkmıştır.

\section{Çözümleyici (Fonik Analiz) Öğretim}

Fonik, çocukların sözcük tanıma etkinlikleri içerisindeyken harf/yazıbirim-ses ilişkisi kurmayı öğrendikleri bir sistemdir (Joseph ve Seery, 2004). Fonik öğretimi yazılı dildeki harfler ile konuşma dilindeki sesler arasındaki köprüyü kurar ve öğrenci konuşma dilindeki seslerin sesbirimsel farkındalığını kazandıktan sonra bu becerisini yeni sözcükleri çözüp yazabilir (Housten ve Torgesen,2004).

Fonik analiz, ses-sembol eşleme, sesleri birleştirme ve sözcükleri ve heceleri seslere bölebilme stratejilerini içerir (Cohen, Heller, Alberto ve Fredrick, 2008; Gottardo ve Rubin, 1991; Hoogeveen, Smeets ve Van der Houven, 1987; Sun ve Kemp, 2006). Araştırmalar eğitilebilir ve öğretilebilir düzeydeki zihin engelli çocukların sembol-ses ilişkisini belleklerinde daha iyi tutabilmelerini sağlayan ve uyaran ile yanıt arasında anlamlı ilişkiler kurmalarına dayalı öğretim yapıldığı zaman fonik becerileri kazanabileceğini ve kullanabildiğini ortaya koymuştur (Al Otaiba ve Hosp, 2004; Browder ve diğerleri 2006; Cohen ve diğerleri, 2008; Gottardo ve Rubin,1991; Joseph ve Seery, 2004; Hedrick ve diğerleri, 1999, Hoogeveen ve diğerleri, 1987; Singh ve Singh, 1986). Gottardo ve Rubin (1991), orta düzeydeki 17 zihinsel engelli çocuğun dil becerilerine öğretim yöntemlerinin etkisini araştırmışlardır. Araştırmada bağımsız değişkenler fonik analiz yöntemi ve görsel sözcük öğretimi iken bağımlı değişkenler ise cümleleri sözcüklere sözcükleri ise hecelere ve seslere bölme becerileri olarak desenlenmiştir. 4 zihin engelli çocuk harf/yazıbirim-ses eşleme ve sesbirimsel farkındalık eğitimi alırken diğer 13 öğrenci görsel sözcük yöntemi ile eğitilmişlerdir. 
Fonik analiz yöntemi ile öğretim gören çocukların bütün bağımlı değişkenlerde görsel sözcük yöntemi ile öğretim gören çocuklardan daha iyi performans sergiledikleri sonucuna ulaşılmıştır.

\section{Sosyal Etkileşimci Yaklaşım}

Zihin engelli çocuklara okuma-yazma öğretiminde yeni ortaya çıkan ve destek gören yaklaşım sosyal etkileşimci yaklaşımdır (Hedrick ve diğerleri, 1999; Katims, 2000, 2001; Wilder, Williams, 2001). Yaklaşım, bütüncül ve etkileşimsel yöntemlerin öğrenme yetersizliği olan çocukların öğrenme ürünlerini geliştireceğini savunur ve temellerini bunun üzerine kurar (Trent ve diğerleri, 1998).

Yaklaşım, temel kavram ve eğitimsel uygulamalarını Vygotsky'nin sosyokültürel teorisinden alır (Harris, Graham,1994; Trent ve diğerleri, 1998). Sosyal etkileşimci yaklaşımın kavramsal çerçevesini çizen dört ana ilke vardır. Bunlar, yapılandırılmış ve düzenlenmiş eğitim ortamlarında öğrenmeye hazırlık/çıraklık dönemi, ifade biçimlerini güçlendirme ve çeşitlendirme, öğrenenin öğrenmelerini kendi kendine düzenlemesine ve kontrol etmesine olanak veren yol gösterici öğretim ve kültürel tarihsel bağlamlar içinde öğrenmedir (Hedrick ve diğerleri,1999; Trent ve diğerleri,1998).

“Tüm Dil Yaklaşımı”, sosyal etkileşimci yaklaşımın özel gereksinimli çocuklar için kullanılan eğitimsel uygulamaları arasındadır (Harris, Graham, 1994; Trent ve diğerleri, 1998). Tüm dil yaklaşımı ile okuma-yazma öğrenmekte zorluk yaşayan çocuklara okuma yazma öğretimi bir yöntem olarak değil bir süreç olarak görülür (Gersten ve Domino, 1993). Öncelikli amaç, okuma ve yazmanın anlamını öğretme, okuduğunu anlama ve sözcükler arasında anlamsal ilișkiler kurma iken, fonik analiz bu beceriler kazandırıldıktan sonra öğretilir. Fonik analiz becerileri öğretilirken de rastgele ve az yapılandırılmış bir öğretim yapılır (Drecktrah, Chiang, 1997; O'Shea, O'Shea, Algozzine, 1998). Beraber kitap okuma, sessiz okuma, koro halinde okuma ve sesli okumalar yaklaşımın eğitim uygulamalarındandır (Katims, 1996; Mandlebaum, 1988; O’Shea ve diğerleri, 1998).

Sosyal etkileşimci yaklaşıma dayalı tüm eğitimsel uygulamalarda bütüncül bir eğitim programı uygulanır. Okuma, yazma, konuşma ve dinleme gibi iletişim alanları arasında oluşturulan yapay engeller dil ile ilgili çeşitli deneyimsel etkinliklerle kırılmaya çalışılır ( O’Shea ve diğerleri, 1998).

Gerçeklik (authenticity) yaklaşımın eğitim uygulamalarında önemli bir faktördür. Öğrenme, işlevsel, anlamlı ve gerçek sosyal ortamlardaki etkinliklerle ilerler. Öğrenciler yapay okul amaçlarının dışına yani gerçek 
iletişim ortamlarındaki etkinliklere dahil edilirler. Öğrenciler hazırlık çalışmalarından çok okuma, yazma gibi dil alıştırmalarında doğrudan yer alırlar edilirler. Destekleyici öğrenme ortamlarında öğretmen öğrencilerin anlam oluşturmalarına yardımcı olur. Sözcükleri doğru okuma ve dilbilgisi gibi teknik bileşenlerin üzerinde durulmaz (Haris ve Graham, 1994; O’Shea ve diğerleri, 1998).

Hedrick ve diğerleri (1999), bir y1l süren betimsel ve deneysel bir çalışma yapmışlar ve yaş ortalamaları 9.8 yaş olan hafif ve orta düzeydeki dokuz zihin engelli çocuğa okuma yazma öğretim programı uygulamışlardır. Araştırmacılar hazırladıkları programda fonik beceri öğretimi gibi geleneksel yöntemler ile sosyal etkileşimci yöntemleri birbirine harmanlayarak öğretim sunmuşladır.

Katims (1996), ilkokul öğrencisi dört hafif düzeydeki zihinsel engelli çocuğa okuma yazma becerilerini geliştirmek için bir yıl süren eğitim uygulamasının etkililiğini deneysel yöntemle araştırmıştır. $\mathrm{Bu}$ eğitim okuryazarlık materyalleri yönünden zenginleştirilmiş, doğal ve gerçek bir sınıf ortamında gerçekleştirilmiştir. Çocuklar okuryazarlık gelişimlerini destekleyecek şekilde eğitim görürken bir yandan da doğrudan eğitim yöntemleri bu etkinliklerin içerisine yerleştirilmiştir. Öğretim sonrasında araştırmadaki dört hafif derecede zihinsel engelli çocuğun okuma ve yazma becerilerinde ustalaştığı görülmüştür.

Alanyazında zihin engelli çocuklara okuma-yazma öğretiminde görsel sözcük öğretimi ile ilgili araştırmalar ağırlık kazanmıştır (Browder ve diğerleri, 2006; Singh ve Singh,1986; Sun ve Kemp, 2006). Zihin engelli çocuklara okuma yazma öğretiminde Türkiye'deki duruma bakıldığında ise konu ile ilgili araştırmaların sınırlı olduğu görülmektedir. Türkiye'de Çolak (2001) ile Batu ve Başal (2002) zihin engelli çocuklara okuma-yazma öğretimde öğretmenlerin kullandıkları yöntemleri belirlemek amacıyla çalışmalar yapmışlardır. Yapılan bu iki araştırmada ülkemizde konu ile ilgili araştırmaların sınırlılı̆̆ına dikkat çekildiği görülmektedir. Yapılan bu araştırmalarda zihin engelli çocuklara okuma yazma öğretiminde ilköğretim birinci sınıflarındaki normal gelişim gösteren çocuklara okuma-yazma öğretiminde kullanılan yöntemlerden farklı bir yöntem kullanılmadığ görülmektedir. Oysa, yurtdışındaki uygulamalarda davranışsal ve sosyal etkileşimci yaklaşım ve yöntemler yoğunluk kazanmıştır. Bu araştırmada Türkiye'deki uygulamalara daha geniş bir örnekler grubu ile bakılacak ve sonuçlar yurt dışındaki uygulamalar ışığında değerlendirilecektir. 


\section{Araștırmanın Amacı}

Araştırmanının genel amacı, özel eğitim öğretmenlerinin zihinsel engelli çocuklara okuma-yazma becerisi kazandırmada kullandıkları yöntemlere ve bu yöntemlerin uygulanmasında izledikleri yollara ilişkin görüşlerini almaktır. $\mathrm{Bu}$ genel amaç doğrultusunda özel eğitim öğretmenlerinin zihin engelli çocuklara okuma-yazma öğretimine geçmeden önce öğrettikleri ön-koşul becerilerin ve öğretimde kullandıkları yöntemlerin, öğretim sırasında kullandıkları materyallerin, değerlendirme yöntemlerinin ve öğretim sırasında karşılaştıkları sorunların neler olduğuna yanit aranacaktır.

\section{YÖNTEM}

\section{Araştırmanın Modeli}

Araştırma, betimsel veri toplamayı amaçlayan tarama türünde bir çalışma olarak desenlenmiştir.

\section{Örneklem}

Tarama türünde araştırmalarda kabaca 100 kişiye ulaşılması hedeflenir (Mertens ve McLoughlin, 2004). Bu araştırmada da, İstanbul'da zihin engelli öğrencilerin eğitiminde görev alan, üniversitelerin zihin engelliler öğretmenliği programından mezun 100 öğretmene ulaşılması hedeflenmiştir. Özel eğitim alanında, üniversitelerin ilgili alanlarından mezunların yanı sıra, alan dışından mezun olup bu alanda çalışan öğretmenler de bulunmaktadır. Ancak alan dışından mezun olup özel eğitim alanında çalışan öğretmenlerin bu alanla ilgili teorik bilgileri oldukça sınırlıdır. Bu nedenle araştırma, zihin engelli öğrencilere okuma-yazma öğretiminin nasıl yapılması gerektiği konusunda eğitim almış olan özel eğitim öğretmenleri ile yürütülmüş̧ür. Örneklemi oluşturacak öğretmenlerin \%70'nin Milli Eğitim Bakanlığı'na bağlı resmi kurumlarda görev yapan öğretmenler ve \%30'nun özel kurumlarda görev yapan öğretmenler olmasına dikkat edilmiştir. Resmi kurumlarda görev yapanlar bir küme, özel kurumlarda çalışanlar da diğer bir kümeyi oluşturmuştur. Resmi kurumlarda görev yapanlar kümesi, İstanbul'da bulunan OÇEM'ler, eğitim ve iş okulu ve kaynaştırma sınıflarının alt kümelerinden oluşmaktadır.

Örneklemin oluşturulmasında ilk aşamada araştırmacı İstanbul İl Milli Eğitim Müdürlüğü'nden İstanbul'daki özel eğitim sınıfı olan okullar, İşeğitim okulları ve OÇEM'lerin listesini almıştır. İkinci aşamada araştırmacı bu okulların her birindeki özel eğitim programı mezunu öğretmen sayısını belirlemek amacı ile okulları aramış ve sayıları öğrenmiştir. Üçüncü aşamada ulaşabilirliğinin daha kolay olduğu rehabilitasyon merkezleri 
aranmış ve bu merkezlerdeki öğretmen sayıları da belirlenmiştir. Bu okul ve merkezlerden üç ve üçten fazla özel eğitim öğretmeni olanlar belirlenmiştir. Örneklem belirlenirken resmi ve özel kurumların İstanbul evreninde bulunma sayılarına göre bir oranlama yapılma yoluna gidilmeksizin ve gönüllülük esasına göre 1 OÇEM'den 12 öğretmen, 7 eğitim ve iş okulundan 48 öğretmen, 7 kaynaştırma sınıfından 7 öğretmen ve 8 rehabilitasyon merkezinden 33 öğretmene ulaşılmıştır. Bir başka deyiş̧le, resmi kurumlarda görev yapanlar kümesi 67 öğretmenden ve özel kurumlarda çalışanlar kümesi 33 öğretmenden oluşmaktadır.

\section{Katılımcıların Özellikleri}

100 katılımcının \%62'sini kadın öğretmenler, \%38'sini erkek öğretmenler oluşturmaktadır. Katılımcıların yaş aralıklarına göre dağılımına bakıldığında \%14'ünün (14 öğretmen) 20-25 yaş aralığında, \%59'unun (59öğretmen) 26-30 yaş aralığında, \%22'sinin (22 öğretmen) 31-35 yaş aralığında, \%5'inin (5 öğretmen) ise $36-40$ yaş aralığında olduğu görülmüştür. Buna göre, örneklem grubunun yarısından fazlasını 25-30 yaş aralığındaki özel eğitim öğretmenleri oluş̧urmaktadır. Katılımcıların zihinsel engelli çocuklarla çalışma yılına göre dağılımına bakıldığında ise ögretmenlerin \%62'sinin (62 öğretmen) 1-5 y1l, \%32'sinin ( 32 öğretmen) 6-10 yıl ve \%6'sının (6 öğretmen) de 11-15 y1l aralıklarında zihinsel engelli çocuklarla çalıştıkları görülmektedir.

Araştırmanın uygulama kısmında araştırmacı her bir kurumu ziyaret etmiş, araştırmanın amacını belirttikten sonra kurumlardaki öğretmenlere veri toplama aracı olan anketi vermiş, katılımcıların anketi doldurmasını beklemiş ve anketleri alarak kurumlardan ayrılmıştır.

\section{Veri Toplama Aracı}

Araştırmada veri toplama aracı olarak "Zihinsel Yetersizliği Olan Öğrencilere Okuma-Yazma Öğretme Konusunda Özel Eğitim Öğretmenlerinin Görüşlerinin Belirlenmesi" isimli anket kullanılmıştır. Araştırmacı tarafından geliştirilen ve beş bölümden oluşan anketin bölümlerinin oluşturulmasında, Çolak'ın (2001) 'Zihin Özürlü Çocuklar İlköğretim Okulu Ve Mesleki Eğitim Merkezindeki Özel Eğitim Öğretmenlerinin Zihin Özürlü Çocukların Okuma-Yazma Öğrenmeleri Hakkındaki Görüş Ve Önerileri' isimli araştırması sonucunda ortaya çıkan temalardan yararlanılmıştır. Zihinsel yetersizliği olan öğrencilere okumayazma öğretimi söz konusu olduğunda öne çıkan başlıklar, özel eğitim öğretmenlerine yönelik hazırlanan anketin de bölümlerinin oluşmasında belirleyici olmuştur. Buna göre anket 5 bölümden oluşmaktadır; 
- Ön-koşul beceriler,

- Öğretim yöntemleri,

- Öğretim materyalleri,

- Değerlendirme yöntemleri,

- Sorunlar

Anketin geliştirilmesi sırasında bölüm başlıkları oluşturulduktan sonra ikinci aşamada bu bölümler altında sorular geliştirilmiştir. Bu soruların oluşturulmasında da Çolak'ın (2001) çalışmasından, ilköğretim birinci sınıf kitaplarından ve öğretim programından yararlanılmıştır. Anket toplamda 25 sorudan oluşmaktadır. Ankette yer alan soruların bölümlere dağılımı şöyledir;

\begin{tabular}{lcccc}
\hline \multicolumn{1}{c}{ Bölümler } & $\begin{array}{c}\text { Açık Uçlu } \\
\text { Soru Sayı1sı }\end{array}$ & $\begin{array}{c}\text { Kapalı Uçlu } \\
\text { Soru Sayısı }\end{array}$ & $\begin{array}{c}\text { Yarı Kapalı } \\
\text { Uçlu Soru } \\
\text { Sayısı }\end{array}$ & Toplam \\
\hline $\begin{array}{l}\text { I. Ön-koşul beceriler } \\
\text { II. Öğretim Yöntemleri }\end{array}$ & 1 & 1 & & 2 \\
$\begin{array}{l}\text { III. Öğretim Materyalleri } \\
\text { IV. Değerlendirme }\end{array}$ & 3 & 3 & 10 & 16 \\
yöntemleri & 1 & & 1 \\
$\begin{array}{l}\text { V. Sorunlar } \\
\text { Toplam }\end{array}$ & 1 & & 1 \\
\hline
\end{tabular}

Anketin birinci bölümünde, öğretmenlerin öğrencilerde gelişmiş olmasını bekledikleri ön koşul beceriler ve bu becerilerin hazır olmadığ 1 durumlarda ne tür çalışmalar yaptırdığı ile ilgili sorular yer almaktadır. İkinci bölümde, öğretmenlerin kullandıkları yöntemleri uygulamakta nasıl bir yol izledikleri, bu yöntemlerin zihinsel yetersizliği olan öğrenciler için uygun olan ve olmayan yönlerinin neler olduğu ve yetersiz olduğunu düşündükleri durumlarda ne tür çözümler ürettikleri açık uçlu soruları oluşmaktadır. Öğretmenlerin kullandıkları yöntemin ne olduğu ve ne tür oyunlara yer verdikleri kapalı uçlu soruları oluşturmaktadır. Yöntemle ilgili yarı açık uçlu sorularda ise sınıf içi grup çalışmaları, öğrencilerle yapılan bireysel çalışmalar ve pekiştireç kullanımı ile ilgili sorular yer almaktadır. Üçüncü bölümde, kullanılan materyallerle ilgili bir soru yer almaktadır. Dördüncü bölümde, öğretimi değerlendirme yöntemleri ile ilgili kapalı uçlu olan bir soru yer almaktadır. Beşinci bölümde ise, öğretim sırasında öğretmenlerin karşılaştıkları sorunların araç-gereç, öğrenci, öğretmen, aile ve okul kaynaklı olup olmadığı araştırılmıştır.

Ankette yer alan sorulardan bazıları, katılımcıların birden çok yanıt vermelerine olanak sağlayacak şekilde hazırlanmıştır. Böylece katılımcıların 
konu ile ilgili görüşlerini sınırlı kalmadan, daha kapsayıcı şekilde ifade etmelerine firsat verilmiştir.

Hazırlanan anket sorularının kapsam geçerliğini sağlamak üzere sorular özel eğitim zihin engelliler öğretmenliği alanından iki uzman tarafından incelenmiştir. Alan uzmanlarının görüşleri doğrultusunda soruların kapsamı ve ifadesinde değişiklikler yapılmış ve veri toplama aracına son şekli verilmiştir.

\section{İşlem}

\section{Verilerin Toplanmast}

Araştırmac1, örneklemi oluşturan öğretmenlerin görev yaptığ1 kurumları ziyaret etmiştir. Kurumlarda yetkili kişilere araştırmanın amacı anlatıldıktan sonra zihin engelliler öğretmenliği programından mezun öğretmenler ile görüşülmüş ve araştırma ile ilgili bilgi verilmiştir. Araştırmanın anketini doldurmak için gönüllü olan öğretmenlere anket araştırmacı tarafindan elden verilmiş ve öğretmenler anketi dolduruncaya kadar araştırmacı kurumlarda beklemiştir.

\section{Verilerin Analizi}

Ankette kapalı uçlu sorular ve açık uçlu sorular olmak üzere iki soru türü bulunmaktadır. Buna bağlı olarak da verilerin analizi iki şekilde yapılmıştır. Kapalı uçlu soruların analizinde, yanıtların sıklığının belirlenmesi yoluna gidilmiştir. Açık uçlu sorular ise betimsel olarak analiz edilmiştir. Anketlerden elde edilen betimsel veriler, Çolak'ın (2001) araştırması sonucunda ortaya çıkan ve anketin bölümlerinin oluşturulmasında da yararlanılan temalar temel alınarak analiz edilmiştir. Açık uçlu soruların analizinde öncelikle, her bir soruya verilen yanıtların tümünün dökümü yapılmıştır. Böylece her soruya verilen toplam yanıt sayısı elde edilmiştir. Yanıtların içinde benzer olanlar birleştirilerek alt temalar oluşturulmuş ve bunların frekansı sayılmıştır.

Araştırmada değerlendiriciler arası güvenirliği belirlemek amacıyla açık uçlu soruların yanıtlarında benzer yanıtların aynı alt maddelerde işlenmesi konusunda iki araştırmacı bağımsız olarak çalışmışlardır. Değerlendiriciler arası güvenirlik hesaplanırken 25 öğretmenin açık uçlu sorularının dökümü kullanılmıştır. İki bağımsız değerlendirici arası güvenirliğin \%80-100 arasında değiştiği, ortalama güvenirliğin \%87 olduğu belirlenmiştir. 


\section{BULGULAR ve YORUM}

$\mathrm{Bu}$ bölümde, araştırma verilerine araştırmanın amacı ve alt temaları doğrultusunda yer verilmiştir.

\section{Ön-Koşul Beceriler}

Araştırmadaki özel eğitim öğretmenlerine, okuma-yazma öğretiminden önce öğrencilerde gelişmiş olmasını bekledikleri ön-koşul becerilerin neler olduğu sorulmuştur. Katılımcilardan gelen yanitlara Tablo 1'de yer verilmiştir.

Tablo 1. Ön-koşul beceriler

\begin{tabular}{lc}
\hline Beceri & F \\
\hline Görsel-işitsel algılama-ayırt etme & 55 \\
İnce-kaba motor gelişim-el kaslarının olgunluğu & 48 \\
Kavram becerileri & 30 \\
Kalem tutma & 29 \\
El-göz koordinasyonu & 19 \\
Alıcı ifade edici dil becerileri, yönerge alma & 18 \\
Sinırlı boyama-çizgi çizme & 16 \\
Eşleme & 15 \\
Sinıflama, sıralama & 14 \\
Dikkati yöneltme, sürdürme & 11 \\
Dinleme, izleme & 10 \\
Örüntü oluşturma & 6 \\
Model alma & 4 \\
Masa başında oturma & 4 \\
Bellekte tutma & 1 \\
Toplam & 280 \\
\hline
\end{tabular}

Ankette bu soruya toplam 280 yanıt gelmiştir. Katılımcilardan gelen 280 görüşün 55'i öğrencilerin görsel, işitsel algılarının ve ayırt etme becerilerinin gelişmiş olması gerektiğini yönündedir. Bunu toplam 280 görüş içindeki 48 görüşle motor gelişimde olgunluk ve el kaslarının olgunluğu takip etmektedir. Temel kavram bilgisine sahip olma (30) ve kalem tutma becerileri öğretmenlerin yoğunlukla gelişmiş olmasını bekledikleri diğer becerilerdir.

\section{Öğretim Yöntemleri}

\section{Kullanılan Yöntem}

Tablo 2'de özel eğitim öğretmenlerinin zihin engelli çocuklara okumayazma öğretimi sırasında kullandıkları yöntemlerin dağılımı görülmektedir. 
Tablo 2. Özel eğitim öğretmenlerinin zihin engelli çocuklara okuma-yazma ögretiminde kullandıklarl yöntemler

\begin{tabular}{lc}
\hline Okuma Yazma Öğretim Yöntemi & N \\
\hline Ses Yöntemi & 55 \\
Cümle/Çözümleme/Fiş Yöntemi & 47 \\
Karma Yöntem & 29 \\
Ses Temelli Cümle Yöntemi & 28 \\
Görsel Sözcük Dağarcı̆̆ & 24 \\
Hece Yöntemi & 23 \\
Harf Yöntemi & 19 \\
Sözcük Yöntemi & 16 \\
Öykü Yöntemi & 9 \\
Diğer & 2 \\
Toplam & 252 \\
\hline
\end{tabular}

Tablo 2 incelendiğinde, öğretmenlerin başlıca 9 yöntemi kullandıkları ve bu yöntemlerin kullanılırlığının ifade edilme sıklıkları görülmektedir. Diğer seçeneği ile birlikte toplam 10 yöntemin öğretmenler tarafından farklı kombinasyonlarda kullanıldığı söylenebilir. Bir başka deyişle, öğretmenlerin sadece bir yöntem değil "öğrencinin özellikleri ve seviyesine göre" ve birden fazla yöntem kullandıkları görülmüştür.

100 özel eğitim öğretmeni kullandıkları yöntemlerle ilgili toplam yanıt sayısı 252 dir. 252 cevabın içerisinde 55 ile ses yöntemi en çok kullanılan yöntemdir. Bunu 47 ile çözümleme yöntemi takip etmektedir. En az kullanılan yöntem ise öykü yöntemidir (9).s

\section{Kullanılan Yöntemlerin Zihin Engelli Çocuklara Uygunluğu}

Araştırmada özel eğitim öğretmenlerine okuma-yazma öğretiminde kullandıkları yöntemin zihin engelli çocuklar için uygun olduğunu düşündükleri yönleri sorulmuştur. Katılımcılardan gelen yanıtlar Tablo 3 'te yer almaktadır.

Tablo 3. Özel ĕgitim öğretmenlerinin kullandıklarl okuma-yazma ögretim yönteminin zihin engelli çocuklar için uygun olduğunu düşündükleri yönleri

\begin{tabular}{lr}
\hline Okuma Yazma Öğretim Yönteminin Uygun Olduğu Yönleri & N \\
\hline Ses yönteminin parçadan bütüne gitmesi-tümevarım & 18 \\
Ses yönteminin basamaklandırılmış olması & 9 \\
Çözümleme yönteminin somut, bütüncül ve anlamlı olması & 9 \\
Ses yönteminin analizine dayalı olması & 7 \\
Çözümleme yönteminin hızlı, akıcı okuma ve anlamayı desteklemesi & 7 \\
Çözümleme yönteminde materyal hazırlama uygunluğu ve esnekliği & 3 \\
Ses yönteminin ezbere dayalı olmaması & 2 \\
Çözümleme yönteminin işlevsel ve eğlenceli olması & 2 \\
Toplam & 57 \\
\hline
\end{tabular}


Katılımcılardan 57 öğretmen bu konuda görüş bildirmiştir. Sonuçlara göre 18 öğretmen ses yönteminin sesten yani parçadan başlamasının zihin engelli çocuklar için uygun olduğunu belirtmiştir. 9 öğretmen ses yönteminin basamaklandırılmıș olmasının, 9 öğretmen çözümleme yönteminin somut, bütüncül ve anlamlı fişlerden oluşmasının zihin engelli çocuklar için uygun olduğunu belirtmiştir.

\section{Öğretim Sırasında Yer Verilen Grup Çalışmaları}

Araştırma grubuna okuma-yazma öğretimi sırasında öğrencilere yaptırdıkları grup çalışmalarının neler olduğu sorulmuştur. Gelen yanıtlara Tablo 4'te yer verilmiştir.

Tablo 4. Özel eğitim ögretmenlerinin okuma-yazma öğretimi sirasında öğrencilere yaptırdıkları grup çalışmaları

\begin{tabular}{lc}
\hline Grup Çalışması & $\mathrm{N}$ \\
\hline Oyunlar (tombala, kelime avı, kelime çarkı, bulmaca vb.) & 39 \\
Sözcük türetme, cümle-hikaye oluşturma & 12 \\
Cümle, metin okuma & 9 \\
Sözcük-resim eşleme & 5 \\
Yazma çalışmaları & 4 \\
Dinleme & 4 \\
Şarkı söyletme & 3 \\
Çizgi çalışmaları/boyama & 3 \\
Dramatizasyon & 2 \\
Film seyrettirme & 1 \\
Tekrar çalışmaları & 1 \\
Toplam & 83 \\
\hline
\end{tabular}

Soruya yanıt veren 60 öğretmenden toplam 83 grup çalışması örneği gelmiştir. 39 öğretmen öğrencilere tombala, kelime avı gibi grup oyunları oynattığını belirtmiştir. 12 öğretmen sözcük türetme, cümle ve hikâye oluşturmaya grup oyunu olarak yer vermektedir. Grupla okuma çalışmalarını ise 9 öğretmen grupla yapılan okuma-yazma çalışması olarak belirtmiştir.

\section{Pekiştireç Kullanımı}

100 özel eğitim öğretmenine öğretim sırasında kullandıkları pekiştireç türleri sorulmuştur. Gelen yanıtlara Tablo 5'te yer verilmiştir. 
Tablo 5. Özel eğitim öğretmenleri tarafindan okuma yazma öğretimi sırasında kullanılan pekiştireç türleri

\begin{tabular}{lr}
\hline Pekiştireç Türü & $\mathrm{N}$ \\
\hline Birincil Pekisstireç & 46 \\
İkincil Pekiştireç & 146 \\
Etkinlik & 28 \\
Nesnel & 19 \\
Sosyal & 64 \\
Sembol & 35 \\
Toplam & 192 \\
\hline
\end{tabular}

Katılımcilardan gelen toplam yanıt sayıs1 192'dir. Cevaplar analiz edilirken birincil ve ikincil pekiştireçler olmak üzere iki ana kategoride değerlendirilmiş daha sonra ikincil pekiştireçler etkinlik, nesnel, sosyal ve sembol olarak ayrılmıştır. Buna göre 192 yanıtın içinde 46 yanıt birincil pekiştireçlerin kullanımı yönündedir. 146 yanıt ise ikincil pekiştireçlerin kullanıldığını göstermektedir. İkincil pekiştireçlerde kendi aralarında dört farklı başlık altında incelendiğinde sosyal pekiştireçlerin (64) oranı en sık kullanılan tür olduğu görülmüştür. Bunu 35 sıklık ile sembol pekiştireçler izlemektedir. Etkinlik pekiştireçleri 28 kullanım sıklığı ile üçüncü sırada yer alırken en son sırada 19 kullanım sıklığı ile nesnel pekiştireçler yer almaktadır.

\section{Öğretim Materyalleri}

Araştırmada özel eğitim öğretmenlerine zihin engelli çocuklara okumayazma öğretiminde kullandıkları materyallerin neler olduğu sorulmuştur. Yanitlar Tablo 6'da yer almaktadır.

Tablo 6. Özel ĕgitim öğretmenlerinin okuma-yazma öğretiminde kullandıklar materyaller

\begin{tabular}{lc}
\hline Materyal Türü & N \\
\hline İlk Okuma Yazma Kitapları & 71 \\
Olay Kartları & 68 \\
Eşleme Kartları & 67 \\
Hece Kitapları & 64 \\
İlkokul Birinci Sınıf Kitapları & 57 \\
Siralama Kartları & 51 \\
Fiş Panosu & 41 \\
Diğer & 30 \\
İlkokul Türkçe Kitapları & 20 \\
Toplam & 469 \\
\hline
\end{tabular}


Tablo 6'da yer alan sonuçlara göre en çok kullanılan materyaller ilk okuma yazma kitapları, olay kartları, eşleme kartları ve hece kitaplarıdır. Fiş panosu ve İlkokul Türkçe kitapları ise öğretmenler tarafından en az kullanılan materyallerdir.

Katılımcılara öğretim sırasında kalem-kağıtla yapılan etkinlikler dışından yer verdikleri oyunların neler olduğu sorulmuştur. Katılımcılardan gelen yanitlara Tablo 7'de yer verilmiştir.

Tablo 7. Özel eğitim ögretmenlerinin okuma-yazma öğretiminde kalem kâğttla yapılan etkinlikler dışında yer verdikleri oyunlar

\begin{tabular}{lc}
\hline Oyun Türü & $\mathrm{N}$ \\
\hline Resim İle Kelime Eşleme & 80 \\
Öğrenilen Fiş/Hece/ Ses/ Metin İle İlgili Resimler Kullanma & 77 \\
Torbadan Fiş/ Hece/ Ses/Resim Çekme & 75 \\
Torbadan Kelimeler Çekme & 71 \\
Kelimeleri Karışık Dizme & 56 \\
Hikaye Kitaplarından Faydalanma & 56 \\
Hecelerden Yeni Kelimeler Oluşturma & 54 \\
Öğrenilen Fiş/Ses/ Metinleri Dramatize Etme & 44 \\
Kelime Çark1 Oyunu & 42 \\
Öğrenilen Metinlerden Şarkılar Oluşturma & 35 \\
Masal Videoları İzletme & 22 \\
Diğer & 14 \\
Toplam & 626 \\
\hline
\end{tabular}

Tabloya bakıldı̆̆ında öğretmenlerden toplam 626 yanıt gelmiştir. 80 yanıt ile resim ile kelime eşleme en sık yer verilen oyun olarak karşımıza çıkmaktadır. Öğrenilen fiş/hece/ ses/ metin ile ilgili resimler kullanma (77), torbadan fiş/ hece/ ses/resim çekme (75), torbadan kelimeler çekme (71) öğretim sırasında sıklıkla yer verilen diğer oyunlardır.

\section{Değerlendirme Yöntemleri}

Araştırma grubuna okuma-yazma öğretiminde öğrencileri değerlendirmek için kullandıkları yöntemlerin neler olduğu sorulmuştur. Soruya gelen yanıtlara Tablo 8'de yer verilmiştir. 
Tablo 8. Özel eğitim öğretmenlerinin okuma-yazma ögretiminde ögrrencileri değerlendirmek için kullandikları yöntemler

\begin{tabular}{lc}
\hline Değerlendirme Yöntemi & $\mathrm{N}$ \\
\hline Gözlem & 75 \\
Bireysel Çalışma Kağıtları & 54 \\
Ölçüt Bağımlı Test & 51 \\
Ders İçi Performans Değerlendirme Formları & 48 \\
Öğretmen Kontrol Listesi & 46 \\
Ödevler & 41 \\
Öz Değerlendirme Formları & 8 \\
Test & 8 \\
Klasik Sınav & 6 \\
Toplam & 337 \\
\hline
\end{tabular}

Araştırma grubunun okuma-yazma öğretiminde öğrencileri değerlendirmek için kullandıkları yöntemlere bakıldığında gelen toplan yanıt sayıs1 337'dir. En sık kullanılan yöntem 75 yanıt ile gözlemdir. Bireysel çalışma kağıtları (54), ölçüt bağımlı test (51), ders içi performans değerlendirme formları (48), öğretmen kontrol listesi (46) ve ödevler (41) sıklıkla kullanılan diğer değerlendirme yöntemleridir. Öğretmenlerinin öğrencilerin okuma-yazma öğrenimindeki genel gelişimini takip etmekte kullandıkları yöntemlere bakıldığında ise gözlem formlarının en sık kullanılan yöntem olduğu ortaya çıkmıştır.

\section{Sorunlar}

\section{Araç-Gereç ve Kaynaklar ile İlgili Sorunlar}

Katılımc1 grubuna okuma-yazma öğretiminde araç-gereç ve kaynakla ilgili karşılaştıkları sorunların neler olduğu sorulmuş ve öğretmenlerden gelen yanıtlara Tablo 9'de yer verilmiştir. 
Tablo 9. Özel ĕgitim öğretmenlerinin okuma-yazma öğretiminde araç-gereç ve kaynakla ilgili karşılaştıkları sorunlara ilişkin görüşleri

\begin{tabular}{|c|c|}
\hline Araç-Gereç ve Kaynak Sorunu & $\mathrm{N}$ \\
\hline Araç-gereç ve kaynakların yetersiz olması & 75 \\
\hline $\begin{array}{l}\text { Okuma yazma öğretiminde kullanılan araç-gereç ve kaynakların zihin } \\
\text { engelli çocukların düzeylerine uygun olmaması. }\end{array}$ & 65 \\
\hline Okuma-yazma öğretiminde tek düze araç-gereç ve kaynakların kullanılması & \\
\hline $\begin{array}{l}\text { Sinıf içinde araç-gereçlerin okuma-yazma öğretimine yönelik } \\
\text { düzenlenmemesi }\end{array}$ & 29 \\
\hline Araç-gereçlerin öğretmene ek yük getirmesi & 18 \\
\hline Diğer & 6 \\
\hline Toplam & 243 \\
\hline
\end{tabular}

Özel eğitim öğretmenlerinin okuma-yazma öğretiminde araç-gereç ve kaynakla ilgili karşılaştıkları sorunlara bakıldığında araç-gereç ve kaynakların yetersiz olması (75) ve araç gereç ve kaynakların zihin engelli çocuklar için uygun olmaması (65) en sık yaşanan sorun olarak karşımıza çıkmıştır.

\section{Öğretmen Kaynaklı Sorunlar}

Katılımcılara öğretim sırasında öğretmenden kaynaklı olduklarını düşündükleri sorunların neler olduğu sorulmuş ve gelen yanıtlar Tablo 10'da gösterilmiştir.

Tablo 10. Özel ĕgitim ögretmenlerinin okuma-yazma öğretiminde ögretmenden kaynaklı olduğunu düşündükleri sorunlara ilişkin görüşleri

\begin{tabular}{lc}
\hline Öğretmen Kaynaklı Sorun & $\mathrm{N}$ \\
\hline Okuma-yazma öğretiminde tek öğretmenin sınıfta yetersiz olması & 60 \\
Lisans eğitiminde verilen okuma-yazma öğretiminin yetersiz olması & 58 \\
Öğretmenlerin okuma-yazma öğretiminde bilgi ve beceri & 51 \\
düzeyinde yetersiz ya da deneyimsiz olması & \\
Öğretmenlerin okuma yazmaya hazırlık becerilerine yeterince ağırlık & 46 \\
vermemeleri & \\
Öğretmenlerin okuma-yazma öğretimindeki tedirginlikleri ve & 22 \\
isteksizlikleri & \\
Ekonomik sorunlar & 13 \\
Diğer & 3 \\
Toplam & 253 \\
\hline
\end{tabular}


Katılımcılardan bu soruya toplam 253 yanıt gelmiştir. Bunların 601 okuma-yazma öğretiminde tek öğretmenin sinıfta yetersiz olmas1 yönündedir. 58 yanıt lisans eğitiminde verilen okuma-yazma öğretiminin yetersiz olması şeklinde belirtilmiştir. 51 yanıt ise öğretmenlerin okumayazma öğretiminde bilgi ve beceri düzeyinde yetersiz ya da deneyimsiz olması yine öğretmenden kaynaklı bir sorun olarak karşımıza çıkmaktadır.

\section{TARTIŞMA ve SONUÇ}

Öğretmenlerin zihin engelli öğrencilerde okuma yazmayı öğrenmeden önce gelişmiş olmasını bekledikleri ön-koşul becerilere ilişkin bulgular öğretmenlerin okuma-yazma öğretiminde davranışsal yaklaşım uygulamalarını kullandıklarını destekler niteliktedir. Çünkü davranışsal yaklaşımda, okuma-yazma öğretimi beceri öğretimi esasına dayalıdır. Öncelikle ön-koşul beceriler öğretilir ve ardından sıralı bir şekilde okumayazma öğretimi yapılır (Hedrick ve diğerleri, 1999; Katims, 2000; Katims, 2000a; Rizopoulos ve Wolpert, 2004).

Araştırmanın bu bulguları Çolak'ın (2001) nitel desenlediği ve özel eğitim öğretmenlerinin zihin engelli çocukların okuma-yazma öğrenmeleri hakkındaki görüşlerini incelediği çalışmanın sonuçları ile paralellik göstermektedir. Çolak'ın araştırmasında da özel eğitim öğretmenlerinin çoğu okuma-yazma öğretimine geçmeden önce okuma yazmaya hazırlık çalışmaları yaptıkları ve bunun okuma- yazma için bir ön-koşul olduğunu belirtilmiştir.

Araştırmada en sık kullanılan yöntemin ses yöntemi olduğu ve sadece bir yöntem değil 'öğrencinin özellikleri ve seviyesine göre' ve birden fazla yöntemin kullanıldığ1 görülmektedir. $\mathrm{Bu}$ araştırmada ortaya çıkan bu sonuçlar Çolak (2001) ile Başal ve Batu'nun (2002) sonuçları ile farklılık göstermektedir. $\mathrm{Bu}$ iki araştırmada öğretimde kullanılan yöntemin cümle çözümleme yöntemi olduğu ortaya çıkmıştır. Çolak (2001) ile Başal ve Batu'nun (2002) araştırmaları yedişer öğretmenle görüşme tekniğine dayalı niteliksel araştırmalardır. $\mathrm{Bu}$ araştırmanın sonuçlarının genellenebilirliği örneklem büyüklüğü göz önüne alındığında diğer iki araştırmadan daha yüksektir.

Son y1llarda zihin engelli çocuklara okuma-yazma öğretiminde görsel sözcük öğretimi ağırlık kazanmış ve fonik analiz öğretimi ikinci planda kalmış ve üzerinde fazla araştırma yapılmamıştır.(Gottardo ve Rubin, 1991; Singh ve Singh, 1986). 2000 yılında yapilan Amerikan Ulusal Okuma Paneli'nde sesbirimsel farkındalık ve fonik beceri okumanın bileşenleri 
olarak tanımlanmıştır (Bradford, Shippen, Alberto, Houchins, Flores, 2006; Browder ve diğerleri, 2006; Housten, Torgesen, 2004). Son yapılan araştırmalarda da hafif, orta ve hatta ağır düzeydeki zihin engelli çocukların harf/yazıbirim-ses ilișkisini ve ses birleștirme becerilerini kazanabileceği yönünde bulgular ortaya çıkmıştır (Bradford ve diğerleri, 2006; Cohen, 2005; Joseph ve Seery; 2004).

Bradford ve diğerleri (2006), orta düzeydeki zihin engelli 3 öğrenciye harf/yazıbirim-ses ilişkisini öğreten program uygulamışlar ve bu becerilerin öğrenciler tarafından genellenebilirliğini öğrenilmeyen sözcükler üzerinde değerlendirmişlerdir. Program sonrasında yapılan değerlendirmelerde öğrencilerin, harf/yazıbirim-ses ilişkisini kavradıkları, sözcükleri okuyabildikleri, sözcükleri okumak için sesleri birleştirebildikleri, sözcükleri seslere ve hecelere bölebildikleri ve cümle ve 2 . sinıf düzeyinde metinler okuyabildikleri görülmüştür.

100 özel eğitim öğretmeninin 60'^ öğretim sırasında grup çalışmaları yaptırdığını belirtmiştir. Bu yönde gelen yanıtların yaklaşık yarısı da grup şeklinde çeşitli oyunlar oynattıkları yönündedir. Bu veriler sosyal etkileşimci yaklaşım 1şığında iki önemli yönden değerlendirilebilir. Birincisi, sosyal etkileşimci yaklaşımda grupla çalışmalar yapmanın önemli olduğudur (Hedrick ve diğerleri, 1999; Katims, 1996; Mandlebaum, 1988). Yaklaşımda grup içindeki paylaşıma dayalı sosyal diyaloglarla öğrenciler kendi stratejilerini düzenlemeyi öğrenirler (Trent ve diğerleri, 1998). İkinci olarak ise O'Shea ve diğerleri (1998) ile Mandlebaum (1988), grup halinde yapılan koro okumalarının öğrencilere okuma becerilerini geliştirmek için grup desteği sağladığını ve güvenlerini arttırdığını belirtmiştir.

Öğretmenlerin öğretim sırasındaki pekiştireç kullanımı ile ilgili görüşleri çeşitlilik göstermektedir. 100 öğretmenden toplam 192 yanıt gelmiştir. Bunların yaklaşık dörtte biri birincil tür pekiştireç kullandığını belirtirken geri kalan çoğunluk ise öğretim sırasında ikincil tür pekiştireç kullandıklarını belirtmiştir. Tekin-İftar ve Kırcaali-İftar (2004), eğitim ortamlarında ikincil pekiştireç bulundurmanın daha kolay olduğunu, daha kullanışlı olduklarını ve daha olağan bir görünüm sergilediklerini söylemektedir. Ayrıca, bu pekiştireçlerle öğrenilen davranışların genellenebilirliği daha yüksek olmaktadır çünkü bireylerin yaşadıkları doğal ortamlarda ikincil pekiştireç alma olasılıkları yüksektir. Yine Tekin-İftar ve Kırcaali-İftar (2004) ikincil pekiştireçler arasında sosyal pekiştireçlerin kullanımının yeğlenmesini çünkü sosyal pekiştireçlerin kullanımının daha kolay, doğal ve ucuz olduğunu belirtmektedir. 
Öğretimde en yoğun olarak ilk okuma-yazma kitapları, olay, sıralama ve eşleme kartları, hece kitapları, ilkokul birinci sınıf kitapları ve fiş panosu kullanılmaktadır. Zihin engelli çocuklara okuma yazma öğretiminde tahmin edilebilirliği yüksek, tekrarlayan kalıpların ve resimlerin olduğu, öğrencinin hikayenin sonrasında ne olacağını kolaylıkla tahmin edebileceği kitapların kullanımı önerilmektedir ( Katims, 1996; 2000; Mandlebaum, 1988; O’Shea ve diğerleri, 1998).

Araştırmaya katılan öğretmenlerin hemen hemen tamamı okuma-yazma öğretiminde oyunlara yer verdiklerini belirtmişlerdir. Öğretimsel oyunlar, etkinlikler ve öğretmenin hazırladığı materyaller okuma yazma öğretiminde öğrencinin ilgisini uyandırır, öğrencinin motivasyonunu arttırır, pratik imkanı sunar, yeni öğrenilen becerileri pekiştirir ve öğretim yönteminde çeşitlilik sağlar (Mercer ve Mercer, 1981).

Gözlem en çok kullanılan değerlendirme yöntemi olarak ortaya çıkmıştır. Bunu bireysel çalışma kâğıtları ve ölçüt bağımlı testler takip etmektedir.

Mercer ve Mercer (1981), tecrübeli öğretmenlerin okuma-yazma öğretiminde her gün dikkatli gözlem yapması gerektiğini söylemektedir. Öğretmenin öğrencilerin okuma becerilerini informal yöntemlerle ve gözlemle değerlendirmek için birçok firsatı olduğunu belirtmektedir.

Araştırmaya katılan öğretmenler okuma-yazma öğretiminde araçgereçlerle ilgili çeşitli sorunlar yaşadıklarını belirtmişlerdir. Çolak'ın (2001) araştırmasında öğretmenler çoğu araç-gerecin yetersiz olduğunu belirtirken bazıları ise okuma yazma öğretimini tek bir Türkçe kitabıyla yürüttüklerini ve daha zengin materyal bulamadıkları için okuma-yazma öğretiminde amaçlarına ulaşamadıklarını belirtmişlerdir. Yine Batu ve Başal'ın (2002) araştırmasındaki öğretmenlerin de çoğu araç-gereçlerin yetersiz olduğunu ve var olan kaynakların da uygun olmadığını belirtmişlerdir.

Okuma-yazma öğretiminde öğretmenlerden kaynaklı sorunlara bakıldığında ise sorunların öğretmenlerin okuma-yazma öğretiminde yetersiz, deneyimsiz ve isteksiz oluşları dikkati çekmektedir. Bu bulgular Çolak'ın (2001) araştırma bulguları ile desteklenmektedir. Bu araştırmada da ögretmenler benzer sorunları ifade etmişlerdir.

\section{Sonuç}

Araştırmada özel eğitim öğretmenlerinin zihin engelli çocuklara okumayazma öğretiminde kullandıkları yöntemlere ve öğretim sırasında izledikleri yollar ile karşılaştıkları sorunlara bakılmıştır. Araştırma sonuçlarında Türkiye'de zihin engelli çocuklara okuma ve yazma öğretiminde normal 
gelişim gösteren çocuklar için kullanılan yöntemlerin kullanıldığı dikkati çekmektedir. Yurtdışındaki uygulamalara bakıldığında ise zihin engelli çocuklar için yaklaşımlar ve bu yaklaşımlar içinde geliştirilmiş olan yöntemlerin olduğu görülmektedir. Yurt dışındaki uygulamalarda görsel sözcük öğretimi, fonik öğretim ve sosyal etkileşimci yaklaşım altındaki uygulamaların yoğunluk kazandığı dikkati çekmektedir. Tüm bu sonuçlara bakılarak ülkemizde de zihin engelli çocuklara okuma-yazma öğretiminde yurt dışındaki uygulamalara benzer yöntemlerin geliştirilmesine gereksinim olduğu söylenebilir.

\section{Uygulama ve İlerideki Araştırmalar için Öneriler}

Türkiye'de zihin engelli çocuklara okuma-yazma öğretiminde yurt dışındaki uygulamalara çok sık yer verilmediği görülmektedir. Bu sonuçlar ışığında öğretimde davranışsal ve sosyal etkileşimci yaklaşım uygulamalarına yer verilebilir. Öğretime zihin engelli çocukların günlük yaşamlarını kolaylaştıracak görsel sözcüklerle başlanabilir. Öğretimde fonik analiz becerilerini öğretmek için harf/yazıbirim-ses eşleme, sesleri birleştirme ile sözcükleri hecelere, heceleri seslere bölme çalışmalarına yer verilebilir. Öğretimde çözümleme aşamasından sonra okuma-yazma becerilerini geliştirmek için çocuklara okuma-yazma materyalleri açısından zengin ortamlar sağlanabilir. Öğretmen çocuklarla beraber kitap okuma, sınıf içinde sessiz okuma ve koro halinde okuma etkinlikleri düzenleyebilir. Sınıf içinde, dikkat çekici materyallerin olduğu yazma köşesi oluşturulabilir. Öğrencilerin, öğrendiklerini genelleyebilmesi için sınıf dışı etkinliklere yer verilebilir. Aileler öğrencilerin öğrendiklerini ev ortamında ve sosyal ortamlarda genelleyebilmeleri için yaptırılabilecek çalışmalar hakkında bilgilendirilebilir. Benzer çalışmalar farklı engel grupları ile çalışan öğretmenlerle yapılabilir, sonuçlar bu araştırmanın sonuçları ile karş1laştırılabilir. Zihin engelli çocuklar için geliştirilmesi düşünülen okuma yazma programlarında araştırmanın bulgularından yararlanılabilir.

\section{KAYNAKLAR}

Al Otaiba, S., \& Hosp, M.K. (2004). Providing effective literacy instruction to students with down sendrome. Teaching Exceptional Children, 36(4), 28-35.

Barudin, S.I., \& Hourcade, J.J. (1990). Relative effectiviness of three methods of reading instruction in developing specific recall and transfer skills in learners with moderate and severe mental retardation. Education and Training in Mental Retardation, 25, 286-291. 
Başal, M. , \& Batu, E. S. (2002). Zihin özürlü öğrencilere okuma yazma öğretme konusuna alt özel sınıf öğretmenlerinin görüş ve önerileri. Özel Ĕ̈itim Dergisi, 3(2), 85-98.

Bradford, S., Shippen, M.E., Alberto, P., Houchins, D.E., \& Flores, M. (2006). Using systematic instruction to teach decoding skills to middle school students with moderate intellectual disabilities. Education and Training in Developmental Disabilities, 41(4), 333-343.

Browder, D.M., \& Lalli, J.S. (1991). Review of research on sight word instruction. Research in Developmental Disabilities, 12, 203-228.

Browder, D. M., Wakeman, S.Y., Spooner, F., Ahlgrim-Delzell,L., \& Algozzine, S. (2006). Research on reading instruction for individuals with significant cognitive disabilities. Exceptional Children, 72(4), 392408.

Cohen, E. T.(2005). Teaching decoding for generalization to students with mental retardation. Unpublished dissertation, Georgia State University.

Cohen, E. T., Heller, K. W., Alberto, P., \& Fredrick, L. D. (2008). Using a three-step decoding strategy with constant time delay to teach word reading to students with mild and moderate mental retardation. Focus on Autism and Other Developmental Disabilities, 23(2), 67-78.

Conners, F.A., Atwell, J.A., Rosenquist, C.J., \& Sligh, A. C. (2001). Abilities underlying decoding differences in children with intellectual disability. Journal of Intellectual Disability Research, 45(4), 292-299.

Çolak, A. (2001). Zihin özürlü çocuklar ilköğretim okulu ve mesleki eğitim merkezindeki özel eğitim ögretmenlerinin zihin özürlü çocukların okuma-yazma ögrenmeleri hakkındaki görüss ve önerileri. Yayımlanmamış yüksek lisans tezi. Anadolu Üniversitesi, Eskişehir.

Dorry, G.W., \& Zeaman, D. (1975). Teaching a simple reading vocabulary to retarded children: effectiveness of fading and nonfading procedures. American Journal of Mental Deficieny, 79(6), 711-716.

Drecktrah, M.E., \& Chiang, B. (1997). Instructional strategies used by generel educators and teachers of students with learning disabilities. Remedial and Special Education, 18(3).

Gattardo, A., \& Rubin, H. (1991). Language analysis skills of children with mental retardation. Mental Retardation, 29(5), 269-274.

Gersten, R., \& Domino, J. (1993). Visions and revisions; a special education perspective on the whole language controversy. Remedial and Special Education, 14(4).

Graham, S., \& Harris, K. R. (1994).Implications of constructivism for teaching writing to students with special needs. Journal of Special Education, 28(3), 275-289. 
Hedrick, W.B., Katims, D., \& Carr, N.J. (1999). Implementing a multimethod, multilevel literacy program for students with mental retardation. Focus on Autism and Other Developmental Disabilities, 14(4), 231-239.

Houston, D. , \& Torgesen, J. (2004). Teaching students with moderate disabilities to read: insights from research. Tallehassee, FL: Bureau of Instructional Support and Community Services.

Hoogeveen, F.R, Smeets, P.M., \& Lancioni, G.E. (1989). Teaching moderately mentally retarded children basic reading skills. Research in Developmental Disabilities, 10, 1-18.

Hoogeveen, F.R, Smeets, P.M., \& van der Houven (1987). Establishing letter-sound correspondences in children classified as trainable mentally retared. Education and Training of the Mentally Retarded, 22, 77-84.

Joseph, L.M., \& Seery, M.E. (2004). Where is the phonics? A review of literature on the use of phonetic analysis with students with mental retardation. Remedial and Special Education, 25(2), 88-94.

Katims, D.S. (1996). The emergence of literacy in elementary students with mild mental retardation. Focus on Autism and Other Developmental Disabilities, 11(3), 147-157.

Katims, D.S. (2000). The quest for literacy:cirruculum and instructional procedures for teaching reading and writing to students with mental retardation and developmental disabilities . Reston, VA: The Council for Exceptional Children.

Katims, D.S. (2000a). Literacy instruction for people with mental retardation: historical highlights and contemporary analysis. Education and Training in Mental Retardation and Developmental Disabilities, 35(1), 3-15.

Katims, D.S. (2001). Literacy assessment of students with mental ratardation: An exploratory investigation. Education and Training in Mental Retardation and Developmental Disabilities, 36(4), 363-372.

Mandlebaum, L. H. (1988). Reading. Greg, A. (Ed). Best practices in mental disabilities, Vol,2. (ERIC Document Reproduction Service No. ED 304843).

Mercer, C.D. \& Mercer, A.R. (1981). Teaching students with learning problems. Ohio:Charles E. Merrill.

Mertens, D.M. \& McLaughlin, J.A. Research and Evaluation Methods in Special Education. California: Corwin Press.

Nichtern, S. (1974). Helping the retarded children. New York:Grosset\&Dunlop.

O'Shea, L. J., O'Shea, D. J., Algozzine, R. (1998). Learning disabilities: From theory toward practice. New Jercey: Merrill. 
Rizopoulos, L. A., \& Wolpert, G. (2004). An overview of the techniques used to develop the literacy skills of adolescents with developmental delays. Education, 125(1), 130-136.

Singh, N.N., \& Singh ,J. (1986). Reading acquisition and remediation in the mentally retarded. International Review of Research in Mental Retardation, 14, 165-196.

Sun, K.K., \& Kemp, C. (2006). The acquisition of phonological awareness and its relationship to reading in individuals with intellectual disabilities. Australasian Journal of Special Education, 30(1), 86-99.

Tekin-İftar, E., \& Kırcaali-İftar, G. (2004). Özel eğitimde yanlışsız öğretim yöntemleri. Ankara:Nobel Yayınlar1.

Trent, S.C, Artiles, A.J. \& Englert, C.S. (1998). From deficit thinking to social constructivism: review of theory, reserach, and practice in special education. Review of Research in Education, 23, 277-307.

Walsh, B.F., \& Lamberts, F. (1979). Errorless discrimination and pictures fading as techniques for teaching sight words to tmr students. American Journal of Mental Deficiency, 83(5), 473-479.

Wilder, A. A., \& Williams, J. P. (2001). Students with severe learning disabilities can learn higher order comprehension skills. Journal of Educational Psychology, 93(2), 268-278. 